warning against the general tendency to over-estimate the potentialities of pure biochemistry. The activities of a living cell as seen under the microscope immediately dispelled any idea that it might be regarded as a bag of enzymes. The fine structure of the cell with its innumerable surfaces and membranes offered a clue to the fundamental question: "Why and how do reactions occur in the right place at the right time ?" The multiplicity of interests disclosed by the staff members of the Wistar Institute, and its strong tradition for morphology should guarantee concentric attacks on essential biological problems.

\title{
THE AUSTRALIAN ACADEMY OF SCIENCE
}

$\mathrm{O}$ May 6, the Governor-General of Australia, Field-Marshal Sir William Slim, opened the new building which houses the offices and conference chamber of the Australian Academy of Science. The establishment of the Academy was initiated by a group of Fellows of the Royal Society of London resident in Australia (Nature, 170, 549; 1952). With the help of other Australian scientific leaders, they set up a body which received a Royal Charter personally from Her Majesty Queen Elizabeth II during her Australian tour in 1954.

The Australian Academy of Science is the representative body of Australian scientists at the national level, with functions comparable with those of the Royal Society of London, which was itself represented at the opening, on May 6, by its senior vice-president, Sir Lindor Brown. The fellowship of the Academy now numbers eighty-seven and up to six new Fellows are elected each year. The president of the Academy since 1957 has been Sir John Eccles, professor of physiology in the Australian National University, Canberra; his predecessor was Sir Mark Oliphant, director of the Research School of Physics in the National University.

In outlining the history of the Academy, Sir John Eccles said that the need for a national scientific body of the highest standing led in 1919 to the formation of the Australian National Research Council, and thanks to the devoted efforts of its leaders, the Council gave most valuable service to Australia. Yet it would be generally agreed that it had failed to achieve the status that was required of a national body with such weighty responsibilities. Various efforts at internal reforms of the Council proved to be impracticable and a more radical proposal emerged from a conference on "Science in Australia" organized by the Australian National University in 1951. At this conference and in the subsequent discussions there was a fairly general agreement that an Academy of Science with much more restricted membership should replace the National Research Council. The Council's executive with great magnanimity agreed to its dissolution in order to make way for the new Academy. This was a fine act of self-sacrifice made in the belief that the new Academy would be better fitted to give leadership in the scientific development of Australia.

The new Academy chose to model itself closely on the Royal Society of London, so taking advantage of three centuries of wisdom. The Academy is also especially indebted to the Royal Society for help in its petitioning for the Royal Charter, and for the gift of a magnificent Signature Book that is a replica of the original Signature Book of the Royal Society.

From the very beginning it has been of prime importance to ensure that the highest standards were maintained in the election to the fellowship, and that it was truly representative of all aspects of pure and applied science. It could be claimed that it has retained the confidence of the general body of scientists in Australia.

The functions of the Academy are both national and international. At the national level there are certain general responsibilities in the fostering of science and in its publication. However, it is at the international level that the Academy has its principal opportunities and functions. First, it is the body representing Australia at all the international scientific unions as well as at the Pacific Science Congress and the Pan Indian Ocean Congress. Secondly, it undertakes international scientific tasks for Australia. The most notable has been the International Geophysical Year, the Academy being responsible for Australia's fine contribution. From the International Geophysical Year there have developed further important international activities in which again the Academy represents Australia. The Special Committee for Antarctic Research and the Committee for Space Research are of vital interest to Australia, and both have achieved a high status. The third meeting of the Special Committee for Antarctic Research was held in Canberra this year and was generally agreed to be very successful. Among other achievements was the inauguration of the International Antarctic Analysis Centre as an annex to the Bureau of Meteorology in Melbourne. Other international activities are the organization of specialist international scientific meetings in Australia. In August a specialist biochemical meeting on hæmatin enzymes was held at the Academy. It is a field in which Australia holds a high place, and many of the leaders in other countries went to Australia for the conference. Next year the Academy is arranging for an international conference on the chemistry of natural products, which will be held in Melbourne, Sydney and Canberra.

In all these national and international activities the Academy can count on the devoted service not only of its own fellowship but also of the other scientists of Australia. The aim is to select the scientists best fitted for these special purposes regardless of their affiliation with the Academy. On the Standing and National Committees of the Academy the Fellows are outnumbered, and often scientists who are not Fellows hold key positions.

There will be no relaxation of labour now that a centre for science has been established in Australia. It has fine symbolism with its geometrical form and its great restraint of line and décor. The Academy can now and in the future radiate its influence over Australia and the world and receive from the world for Australia. But every end is a new beginning; and the Academy is now planning to become as well a channel for benefactions for scientific purposes and so to exert its influence not only through expert committees and individually by its Fellows but also 


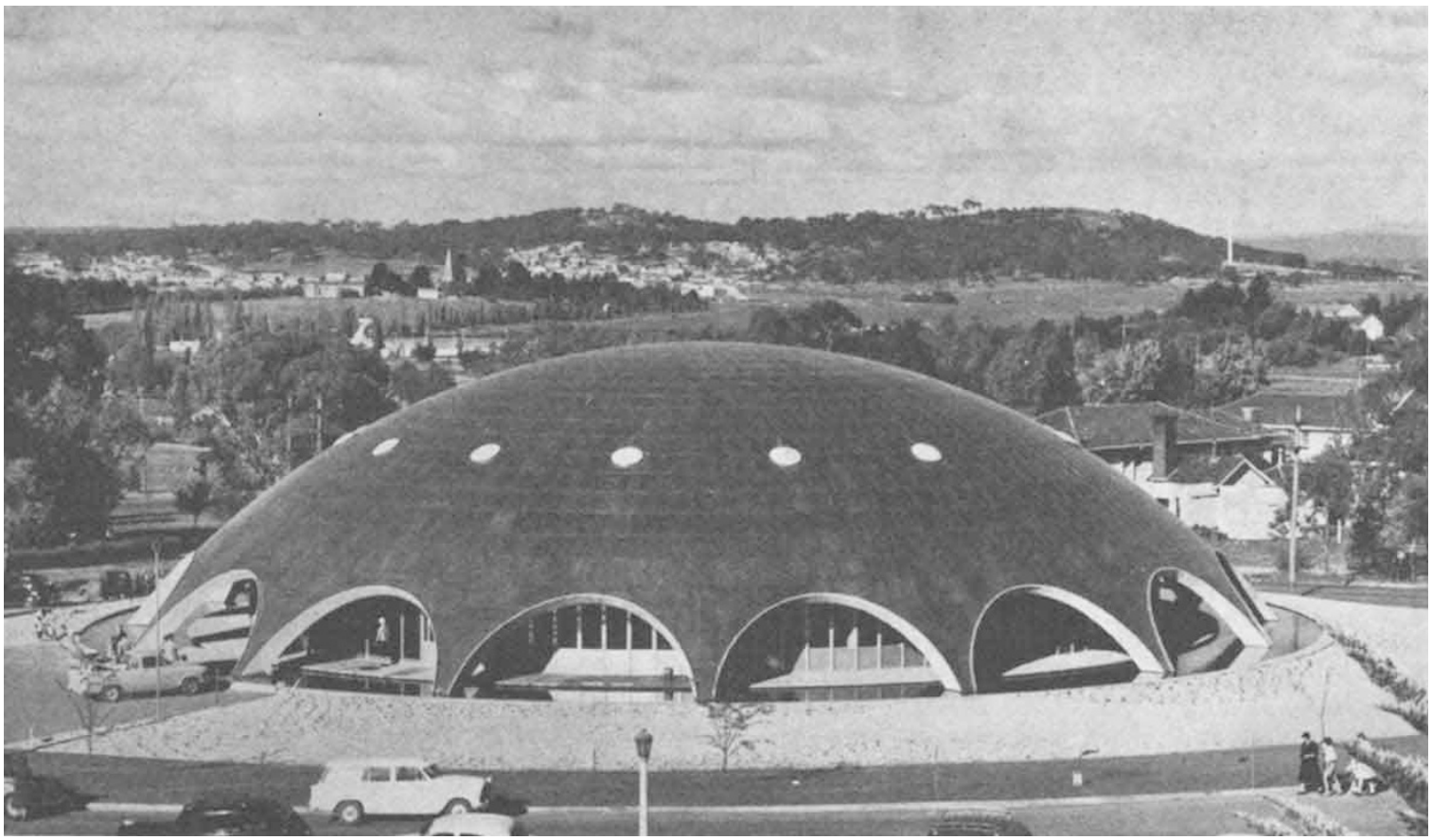

Fig. 1. New Building of the Australian Academy of Science, in Gordon Street, Canberra

by providing the finance for research projects. Benefactors would be secure in the knowledge that their contributions were being administered by the collective scientific wisdom of the Academy, rather than by the authority of any one scientist, however eminent.

The copper-sheathed dome of the new Academy building (Fig. 1), rising from the waters of a surrounding moat, is backed by the rolling bronze-green hills of Australia's national capital, Canberra. Beneath the dome is a central conference chamber, with luxurious seating for 190 and comfortable seating for a further 100, and a ring of offices, council room, and a superb reception room which overlooks an expanse which will within a few years be part of the central lake-system of Canberra. The conference chamber will be the venue of the annual meetings of the Academy itself, and will be extensively used for meetings of Australian scientific and professional societies, as well as for such international symposia as may be held in Australia.
The national responsibilities of the Academy receive material recognition from the Commonwealth Government in the form of an annual grant towards current expenses. The Academy, however, remains autonomous, and indeed the value of its services is derived very largely from its autonomy. It is too young a body to have achieved financial self-sufficiency through endowments; but the erection of the conference chamber and offices has been made possible entirely because of generous contributions to the Academy building fund by Australia's great industrial firms. To these firms, to the architects, and to the vision and energy of the members of its early Councils, the Australian Academy of Science, and Australia, owe a debt of gratitude; for they have created one of the most striking and important structures in Canberra, and they have provided the Academy with a home of its own which is modern, dignified, and of the highest quality.

\title{
MERLIN; AN INDUSTRIAL RESEARCH REACTOR
}

\author{
By DR. T. E. ALLIBONE, F.R.S.
}

Research Laboratory, Associated Electrical Industries, Ltd., Aidermaston Court, Berkshire

$\mathrm{T}$ HE Merlin research reactor is situated at the Research Laboratory of Associated Electrical Industries, Itd., at Aldermaston Court in Berkshire. It was made critical for the first time on July $16,1959$.

The decision to install a reactor for fundamental research at Aldermaston was taken in 1955 and the Associated Electrical Industries-John Thompson Nuclear Energy Co. undertook to supply it. The nuclear physics aspects of the reactor and the design of the control system have been the responsibility of the Associated Electrical Industries Research
Laboratory ; the mechanical engineering design, the erection and the commissioning of the equipment up to the stage of loading fuel into the reactor have been the responsibility of Associated Electrical Industries-John Thompson. Loading of fuel began on July 6 by the staff of the Laboratory, who are now engaged on the proving trials of the reactor. These trials, which involve thermal, mechanical, electrical and physical measurements, will extend into 1960 , while the reactor power is gradually increased to a maximum of $5 \mathrm{MW}$. 